\title{
Formulation, characterization and in vivo evaluation of novel edible dosage form containing nebivolol $\mathrm{HCl}$
}

\author{
Pujari Vijayanand ${ }^{1, *}$, Jagadevappa Patil², Manda Venkata Reddy ${ }^{3}$
}

\author{
${ }^{1}$ Department of Pharmaceutical Sciences, Jawaharlal Nehru Technological University, Kakinada, Andhra Pradesh, India \\ ${ }^{2}$ VT Trust, Shivaji Rao Jondhle College of Pharmacy, Asangaon, Maharashtra, India, ${ }^{3}$ Sree Dattha Institute of Pharmacy, \\ Sheriguda, Ibraimpatnam, Hyderabad, India
}

\begin{abstract}
The objective of this investigation was to develop a novel oral edible gel dosage form for nebivolol hydrochloride, with suitable rheological characteristics that can provide a means of administering the drug to dysphagic and geriatric patients. Edible gels were prepared using low acetylated gellan gum and sodium citrate in different concentrations. The effect of concentration of the solution on gelation time, viscosity, and drug release was studied. Optimized formulation had "spoon thick" consistency that is considered suitable for dysphagic patients as suggested by National Dysphagia Diet Task Force. The optimized formulation containing gellan gum $(0.4 \% \mathrm{w} / \mathrm{v})$ and sodium citrate $(0.3 \% \mathrm{w} / \mathrm{v})$ showed more than $95 \%$ drug release in 20 minutes. This formulation also showed significantly better pharmacokinetic profile when compared to marketed conventional tablets in New Zealand white rabbits $(n=3)$. Optimized formulation was found stable for 6 months when stored at $25^{\circ} \mathrm{C} \pm 0.2{ }^{\circ} \mathrm{C} / 60 \pm 5 \% \mathrm{RH}$. From this study, it can be concluded that the novel edible gel dosage form containing nebivolol hydrochloride may prove to be more efficacious in the treatment of hypertension in dysphagic patients.
\end{abstract}

Uniterms: Edible gel/pharmaceutics. Nebivolol HCl/delivery. Dysphagia/drugs administration.

O objetivo deste trabalho foi desenvolver um gel comestível para veiculação de cloridrato de nebivolol, com características reológicas adequadas, que podem fornecer meio de administrar o fármaco em casos de disfagia orofaríngea e pacientes geriátricos. Géis comestíveis foram preparados utilizando goma gelana de baixa acetilação e citrato de sódio, em diferentes concentrações. Estudou-se o efeito da concentração da solução no tempo de gelificação, a viscosidade e a liberação do fármaco. A formulação otimizada apresentava consistência de pudim, o que é considerado adequado para pacientes disfágicos como sugerido pela National Dysphagia Diet Task Force. A formulação otimizada contendo $0,4 \%(\mathrm{~m} / \mathrm{v})$ de goma gelana e $0,3 \%(\mathrm{~m} / \mathrm{v})$ de citrato de sódio mostrou que mais de $95 \%$ de fármaco foi liberado em 20 minutos. Esta formulação também mostrou, significativamente, melhor perfil farmacocinético, quando comparado com os comprimidos convencionais comercializados administrados a coelhos brancos neozelandeses $(n=3)$. A formulação otimizada manteve-se estável durante 6 meses, armazenada a $25^{\circ} \mathrm{C} \pm 0,2{ }^{\circ} \mathrm{C} / 60 \pm 5 \%$ de UR. A partir deste estudo, conclui-se que a nova forma de gel comestível contendo cloridrato de nebivolol pode ser mais eficaz no tratamento de hipertensão em pacientes portadores de disfagia.

Unitermos: Gel comestível/farmacotécnica. Cloridrato de nebivolol/veiculação. Disfagia/administração de fármacos.

\footnotetext{
*Correspondence: P Vijayanand. Sri Venkateshwara College of Pharmacy. 86, Hi Tech City road - Madhapur - Hyderabad - Telangana 500081, India. E-mail: vijay.svcp@gmail.com, pharmajspatil@gamil.com, venkat_manda60@yahoo.com
} 


\section{INTRODUCTION}

Oral administration of drugs is most preferred because of its ease of ingestion, no pain and improved patient compliance. However, dysphagic patients experience difficulty in swallowing with existing oral dosage forms such as tablets and capsules. Administration of oral liquids may result in choking in these patients (Dixit, Parthasarathi, Hosakote, 2011). Moreover, elderly patients cannot easily take tablets or capsules. The physical injury caused upon rubbing of the solid preparation against mucous membrane can discomfort the patient (Dixit, Parthasarathi, Hosakote, 2011). Crushing of enteric coated tablets or controlled release tablets is undesirable, as this may lead to loss of efficacy of the dosage form (Jackson et al., 2008).

Dysphagia is a biomechanical disorder considered as a clinical syndrome (PBM, 2006). It is defined as "an inability to swallow, or a sensation that solids or liquids do not pass easily from the mouth to the stomach" (PBM, 2006). From many reported studies it has been estimated that over six million adults have dysphagia (PBM, 2006). It can occur in all age groups, but the prevalence increases with increase in age and in Parkinson's disease (PBM, 2006; Shirley, 2013).

Nebivolol $\mathrm{HCl}$ (NEB) is a cardio selective third generation $\beta$-receptor blocking agent, used orally in the treatment of hypertension (Bystolic, 2007). After oral administration, it reaches peak plasma concentration within $0.5-2 \mathrm{~h}$. Oral bioavailability of NEB is only $12 \%$ in extensive metabolizers (majority of the population) as it undergoes extensive first pass hepatic metabolism due to cytochrome P450 2D6 (CYP2D6) enzymes. Half-life also varies extensively from $10.3 \mathrm{~h}$ to $31.9 \mathrm{~h}$ in extensive and poor metabolizers respectively. The recommended dose of NEB is $5 \mathrm{mg}$ per day. Depending on the blood pressure (BP) of the patient, dose may be increased slowly at 2 weeks intervals to a maximum of up to $40 \mathrm{mg}$ per day (Hilas, Danielle, 2009).

Hypertension is a common disease of the elderly. From the literature, we know that $60-80 \%$ of the elderly patient population (age above 60-65 years) suffer from hypertension (Malyszko et al., 2013). Further, there are several factors that cause dysphagia. Of these, senescence is a major factor. Many of these older patients who suffer from dysphagia also concomitantly suffer from hypertension. Therefore, there exists some white space for the development of edible dosage forms for elderly patients suffering from dysphagia coupled with other chronic diseases like hypertension. In this work, we used NEB as a model drug and it was selected owing to its high prescription volumes and poor oral bioavailability $(\sim 12 \%$ in humans).

Thickened liquids play a vital role in reducing risk of aspiration for dysphagic patients. Previous studies have indicated the importance of viscosity as a bolus variable during the swallowing process (Bisch et al., 1994; Dantas et al., 1990). Dietary professionals work closely with the speech-language pathologists to determine the appropriate consistencies of fluid for each patient (Duke Medicine, 2007; Wexner Medical Center, 2013). In 2002, the American Dietetic Association established the National Dysphagia Diet (NDD) guidelines for thickened dietary supplements (Gary, Cathy, Catriona, 2003). To ensure safety during oral administration, patients with dysphagia require an appropriate oral dosage form or modification of the dosage form.

There is clearly a need for a suitable dosage form that can address the low bioavailability of NEB and also eases the administration of drugs to dysphagic patients. This study tries to address the same by formulating NEB into novel oral edible gel (OEG) dosage form. We formulated the OEG using gellan gum as polymer and assessed the in-vitro and in-vivo performance of the same.

\section{MATERIAL AND METHODS}

\section{Material}

Nebivolol $\mathrm{HCl}$ was obtained as gift sample from Aurobindo Pharma, Hyderabad, India. Gellan gum was gift sample from Mylan laboratories Ltd, Hyderabad, India. PEG 400, citric acid, mannitol, methyl paraben, were purchased from ESSEL fine chem., Mumbai, India. Strawberry flavor was purchased from Robin chemicals, Mumbai. Sucralose was obtained from J.K. Suralose Inc. Ltd., Delhi. All other ingredients used were of analytical reagent grade.

\section{Methods}

\section{Formulation of oral edible gel}

All ingredients were passed through ASTM sieve \# 60 and accurately weighed. The details of the composition are shown in Table I. Gellan gum powder was dispersed in $50 \mathrm{~mL}$ of distilled water maintained at $95^{\circ} \mathrm{C}$. The dispersion was stirred at same temperature for $20 \mathrm{~min}$ using a magnetic stirrer (Remi PMDC, Mumbai, India) to facilitate hydration of the gellan gum. The required amount of mannitol was added to the gellan gum solution with continuous stirring. NEB was then added to it under stirring. Citric acid, methylparaben were added and mixed. Sodium citrate 
previously dissolved in $10 \mathrm{~mL}$ distilled water was added to the mixture. Strawberry flavor was added at last when temperature reached below $40^{\circ} \mathrm{C}$. Weight of the gel was adjusted finally to $100 \mathrm{~g}$ with distilled water. The mixture was allowed to cool to room temperature to form gel. The gels were prepared using five different concentrations of gellan gum $(0.1,0.2,0.3,0.4$ and $0.5 \% \mathrm{w} / \mathrm{v})$, each with two different sodium citrate concentrations $(0.3$ and $0.5 \% \mathrm{w} / \mathrm{v})$ (Mohapatra, Parikh, Gohel, 2008).

\section{Evaluation of oral edible gel}

Oral edible gels were subjected to various evaluation parameters.

\section{- Determination of gelation time}

Gelation time was determined by placing the prepared gel in $20 \mathrm{~mL}$ flat bottomed cylindrical vial maintained at $25 \pm 0.2{ }^{\circ} \mathrm{C}$. The gelation time was considered as the time taken for the formulation to convert from "sol" state to "gel" state (Hanawa et al., 1995).

- Appearance and texture evaluation of the gel

Texture of the gel was evaluated in terms of stickiness and grittiness by mildly rubbing the gel between two fingers (Gohel et al., 2009). The gel formulations were visually inspected for transparency.

- $\mathrm{pH}$ of the edible gel

$\mathrm{pH}$ influences stability and taste of the final formulation. Hence, the $\mathrm{pH}$ of edible gel was measured using digital $\mathrm{pH}$ meter by checking the $\mathrm{pH}$ of a $10 \% \mathrm{w} / \mathrm{v}$ gel-dispersed in purified water at $25 \pm 0.5^{\circ} \mathrm{C}$ (Mohapatra, Parikh, Gohel, 2008; Dabhi et al., 2011).
- Syneresis

Separation of water by contraction of the gel upon standing is known as syneresis. Syneresis is more pronounced in the gel where very low concentration of gelling agent is used. Prepared gels were kept under scrutiny for signs of syneresis in refrigerator $\left(4-8^{\circ} \mathrm{C}\right)$ for 90 days (Mohapatra, Parikh, Gohel, 2008; Dabhi et al., 2011; Gerentes et al., 2002).

\section{- Fourier Transform Infrared Spectroscopy (FTIR)} studies

FTIR studies were performed to find any possible drug-excipient interaction by $\mathrm{KBr}$ pellet method using Perkin-Elmer spectrophotometer, USA (Model-1615). For this study, physical mixtures of drug and excipient $(1: 1)$ were prepared and co-ground with $\mathrm{KBr}$. The resultant mixture was subjected to FTIR studies. Scans were performed from $400-4000 \mathrm{~cm}^{-1}$ and an average of 40 scans were taken per sample.

- Differential scanning calorimeter (DSC) studies

Differential scanning calorimetry (DSC) was performed on pure NEB and optimized gel formulation. Calorimetric analysis was carried out using DSC 60 (Shimadzu Corporation, Kyoto, Japan) instrument. Briefly, accurately weighted sample was taken in an aluminum pan and crimp sealed. In the DSC chamber, samples were allowed to equilibrate at $25^{\circ} \mathrm{C}$. Then, the samples were subjected to heating run over temperature range of $25-300{ }^{\circ} \mathrm{C}$ at a heating rate of $5^{\circ} \mathrm{C} / \mathrm{min}$. DSC curves were directly obtained from the software supplied with the instrument (Punna Rao et al., 2014).

TABLE I - Formulation of oral edible gel

\begin{tabular}{lcccccccccc}
\hline \multirow{2}{*}{ Ingredients } & \multicolumn{1}{c}{ Formulations } \\
\cline { 2 - 11 } & F1 & F2 & F3 & F4 & F5 & F6 & F7 & F8 & F9 & F10 \\
\hline Nebivolol (mg) & 200 & 200 & 200 & 200 & 200 & 200 & 200 & 200 & 200 & 200 \\
Gellan gum (\%) & 0.1 & 0.1 & 0.2 & 0.2 & 0.3 & 0.3 & 0.4 & 0.4 & 0.5 & 0.5 \\
PEG 400 (\%) & 0.2 & 0.2 & 0.2 & 0.2 & 0.2 & 0.2 & 0.2 & 0.2 & 0.2 & 0.2 \\
Citric acid (\%) & 0.05 & 0.05 & 0.05 & 0.05 & 0.05 & 0.05 & 0.05 & 0.05 & 0.05 & 0.05 \\
Mannitol (\%) & 30 & 30 & 30 & 30 & 30 & 30 & 30 & 30 & 30 & 30 \\
Sucralose (\%) & 0.3 & 0.3 & 0.3 & 0.3 & 0.3 & 0.3 & 0.3 & 0.3 & 0.3 & 0.3 \\
Sodium citrate (\%) & 0.3 & 0.5 & 0.3 & 0.5 & 0.3 & 0.5 & 0.3 & 0.5 & 0.3 & 0.5 \\
Methyl paraben (\%) & 0.2 & 0.2 & 0.2 & 0.2 & 0.2 & 0.2 & 0.2 & 0.2 & 0.2 & 0.2 \\
Strawberry (\%) & 2 & 2 & 2 & 2 & 2 & 2 & 2 & 2 & 2 & 2 \\
Water (\% w/w) up to & 100 & 100 & 100 & 100 & 100 & 100 & 100 & 100 & 100 & 100 \\
\hline
\end{tabular}

$\mathrm{PEG}=$ Polyethylene glycol. 


\section{- Viscosity and consistency}

Gels were prepared according to the viscosity guidelines given by national dysphagia diet task force (Dixit, Parthasarathi, Hosakote, 2011). Viscosity of the all the batches of gels was measured using Brookfield DV-II+Pro viscometer using spindle number LV4 at the rotation of $50 \mathrm{rpm}$ at room temperature. The viscosity measurements were made in triplicate using fresh samples each time (Mohapatra, Parikh, Gohel, 2008).

\section{- Drug content assay}

A known quantity of gel $(5 \mathrm{~g})$ was taken in a $30 \mathrm{~mL}$ volumetric flask containing solvent system methanol: water $(80: 20 \% \mathrm{v} / \mathrm{v})$. This was then shaken on a mechanical shaker for $1 \mathrm{~h}$ to get a homogeneous solution that was filtered (Whatman 0.45 micron PVDF syringe filter). The drug content was determined using HPLC after appropriate dilution (Sahoo, Giri, 2009). Experiment was performed in triplicate. The gels were considered to comply with the test if, not more than one of the values obtained was outside the limits of $85-115 \%$ of the average value and none was outside the limits 75-125\% (USP, 2000).

- In vitro drug release studies and release kinetics

In vitro drug release from the gels were studied using USP XXIV dissolution apparatus II (Electrolab, Mumbai, India) employing a paddle stirrer at $100 \mathrm{rpm}$ using $900 \mathrm{~mL}$ of $\mathrm{pH} 6.8$ phosphate buffer at $37 \pm 0.5^{\circ} \mathrm{C}$ as a dissolution medium (Raju et al., 2011). $5 \mathrm{~g}$ of gel formulation was accurately weighed and placed at the bottom of the dissolution vessel. Aliquots ( $5 \mathrm{~mL}$ each) were withdrawn at specified time intervals $(2,4,6,8,10$, $12,14,16,18,20,25$ and $30 \mathrm{~min}$ ) and media replaced with equal volume each time. All the studies were done in triplicate $(n=3)$. The samples were analyzed for drug content using HPLC (Sahoo, Giri, 2009). The drug release profile was fitted into several mathematical models like zero order, first order kinetics, Higuchi and Peppas model to get an insight of release mechanism of the drug from the dosage form.

\section{- Chromatographic conditions}

The HPLC was used for determination of drug content assay and in-vitro drug release studies. The details of the study are as follows: Instrument: Shimadzu LC-10AT and LC-10AT VP series HPLC pumps; Mobile Phase: Methanol:Water $(80: 20, \mathrm{v} / \mathrm{v})$; Column type: Hypersil ODS C18 (250 x $4.6 \mathrm{~mm}, 5 \mu \mathrm{m})$; Wavelength: $282 \mathrm{~nm}$; Flow rate: $1 \mathrm{~mL} / \mathrm{min}$; Detector type: SPD 10A VP UV-Visible absorbance detector. The linearity range was: 1 to $450 \mu \mathrm{g} / \mathrm{mL}$; Limit of Detection was $100 \mathrm{ng} / \mathrm{mL}$ and the Limit of Quantification was $250 \mathrm{ng} / \mathrm{mL}$ (Sahoo, Giri, 2009).

\section{- Stability studies}

Optimized gel formulations were stored in highdensity polyethylene bottles at $25^{\circ} \mathrm{C} \pm 0.2{ }^{\circ} \mathrm{C} / 60 \pm 5 \%$ $\mathrm{RH}$ and $40 \pm 2{ }^{\circ} \mathrm{C} / 75 \pm 5 \% \mathrm{RH}$ in a stability chamber (Ostwald stability chamber JRIC-11) for 6 months and 3 months respectively. Samples were withdrawn with 30 days intervals up to 6 months and were evaluated for their physical appearance, $\mathrm{pH}$, viscosity, assay and drug release (Dixit, Kulkarni, 2012).

\section{- In vivo studies}

The in vivo studies were performed in male New Zealand white rabbits $(n=6)$. Animal ethical committee clearance was taken before performing the experiment (CPCSEA/IAEC/EXP/25/50/2013/EXP-02). The rabbits were fasted overnight $(12 \mathrm{~h}$ ) before administration of the formulations. The animals were randomly divided into two groups (A and B) with three animals in each group. Group A rabbits were anaesthetized with intravenous injection of pentobarbital at a dose of $25 \mathrm{mg} / \mathrm{kg}$ (Setouhy, Malak, 2010). Then they were positioned on a table with the lower jaw supported in a horizontal position (Kishore et al., 2013). The gel formulation was carefully placed on the tongue of group 'A' rabbits. As a control, marketed tablet (Nebicard, Torrent Pharmaceuticals limited, India) was administered orally by dispersing it in $2 \mathrm{~mL}$ of water to group ' $\mathrm{B}$ ' rabbits via oral gavage (Kishore et al., 2013). The dose of $10 \mathrm{mg} / \mathrm{kg}$ body weight was chosen for the study based on previously reported literature (Punna Rao et al., 2015).

Blood samples $(1 \mathrm{~mL})$ for pharmacokinetic analysis were obtained by marginal ear vein puncture at different time intervals $(0,15,30,45,60,120,240,360,480 \mathrm{~min}$, 12,24 and $36 \mathrm{~h}$ ) post dosing. Blood samples were collected in microfuge tubes containing sodium citrate $(3.4 \% \mathrm{w} / \mathrm{v})$ as an anticoagulant. To separate the plasma, sample were centrifuged for $10 \mathrm{~min}$ at $3,500 \mathrm{rpm}$ at $4{ }^{\circ} \mathrm{C}$ temperature. The method reported by Punna Rao et al. was used for analysis of drug plasma samples after suitable partial validation in rabbit plasma (Punna Rao et al., 2015).

\section{- Statistical analyses}

Unpaired Student's t-test at 95\% CI was used to determine the significance in difference of mean viscosities as a function of gellan gum and sodium citrate concentrations. In the in-vitro drug release studies, we used linear regression analysis to identify the best-fit model to describe the drug release kinetics from the optimized formulation. In the in-vivo studies, unpaired Student's 
t-test at $90 \%$ CI was used to assess the difference between the pharmacokinetic paramters $\left(\mathrm{C}_{\max }, \mathrm{T}_{\max }\right.$ and AUC) obtained after dosing marketed and test formulations.

\section{RESULTS AND DISCUSSION}

\section{Determination of gelation time}

It was found that formulations F1 to F4 did not form a gel and remained in a honey-like consistency. Hence, these formulations were not considered for further studies. Formulations F5 and F6 formed spoon thick gel within 30 minutes of preparation and formulation $\mathrm{F} 7$ to F10 formed gel immediately at the end of the preparation. Data shown in Table II.

\section{Appearance and texture evaluation}

All the formulated gels were translucent in appearance. As shown in Table II, formulations F1 to F6 were non-sticky and non-gritty. Formulations F7 and F8 were slightly sticky and non-gritty. Formulations F9 and F10 were sticky and slightly gritty in nature as determined visually and by mildly rubbing between two fingers. Stickiness of gel formulations increased with increase in concentration of the polymer.

\section{$\mathrm{pH}$ of the gel and syneresis}

$\mathrm{pH}$ and syneresis are interconnected to each other (Setouhy, Malak, 2010). pH has an influence on syneresis. Hence, adjustment of $\mathrm{pH}$ plays an important role in preventing syneresis (Dixit, Parthasarathi, Hosakote, 2011). Moreover, $\mathrm{pH}$ also has an influence on taste of the final formulation. Syneresis is one of the major problems associated with gels where very low concentration of gelling agent is used. Formulations F7 to F10 did not show any signs of syneresis during storage between $4-8{ }^{\circ} \mathrm{C}$ in refrigerator for 90 days. Hence, these gel formulations were selected for further studies. Slight syneresis was observed in formulations F5 and F6. This could be due to low polymer concentration in the formulation. Hence, these formulations were not considered for further studies. Data are shown in Table II.

\section{FTIR}

FTIR studies were performed on pure drug and physical mixture of the gel formulation. All characteristic peaks of NEB were present in their original positions, denoting the absence of drug-excipient interaction. FTIR spectrum of NEB shows characteristic peaks at $3195 \mathrm{~cm}^{-1}$ (O-H stretching), 2982, 2921, $2848 \mathrm{~cm}^{-1}$ (C-H stretching), and $1621,1544 \mathrm{~cm}^{-1}(\mathrm{C}=\mathrm{C}$ stretching $), 1302 \mathrm{~cm}^{-1}(\mathrm{C}-\mathrm{N}$ stretching) and $1139 \mathrm{~cm}^{-1}$ (C-O stretching). IR spectra are shown in Fig. 1. From the figure, no shifts in peak positions were observed for pure NEB (Fig. 1. A), in physical mixture of the gel formulation (Fig. 1. B).

\section{DSC}

DSC curve (Fig.2 A) shows a sharp endotherm at $228^{\circ} \mathrm{C}$ that corresponds to NEB. However, as seen in Fig. 2 B, the NEB peak is absent. Apparently, the drug is in a dissolved/amorphous state within the gel matrix. Peak at $72{ }^{\circ} \mathrm{C}$ in Fig. $2 \mathrm{~B}$, corresponds to that of gellan gum.

\section{Viscosity and consistency}

Normally, the process of oral swallowing happens at a shear rate of $\sim 50 / \mathrm{s}$ at $25^{\circ} \mathrm{C}$. Perceptual viscosity discrimination studies have been used to estimate the

TABLE II - Evaluation of edible gel formulations

\begin{tabular}{lccccccccccc}
\hline \multirow{2}{*}{ SL.No } & Evaluation & \multicolumn{10}{c}{ Formulations } \\
\cline { 3 - 12 } & parameters & F1 & F2 & F3 & F4 & F5 & F6 & F7 & F8 & F9 & F10 \\
\hline 1 & Gelation time (min) & + & + & + & + & 30 & 30 & ++ & ++ & ++ & ++ \\
2 & pH of gel & 5.63 & 5.68 & 5.58 & 5.67 & 5.70 & 5.75 & 5.78 & 5.80 & 5.68 & 5.73 \\
3 & Syneresis & - & - & - & - & No & No & No & No & No & No \\
4 & Texture & NS, NG & NS, NG & NS, NG & NS, NG & NS, NG & NS, NG & SS, NG & SS, NG & S, SG & S, SG \\
5 & Viscosity (cps) & 512 & 837 & 1563 & 1835 & 2776 & 3826 & 5107 & 7854 & 8948 & 9685 \\
6 & Consistency & Honey & Honey & Honey & Honey & Spoon & Spoon & Spoon & Very & Very & Very \\
& & like & like & like & like & thick & thick & thick & thick & thick & thick \\
\hline
\end{tabular}

*NS- Non Sticky, NG- Non Gritty, SS- Slightly Sticky, S - Sticky, SG- Slightly Gritty '+'indicates complete gel has not been formed and consistency remained honey like, '++' indicates gel has formed immediately at the end of the preparation. 


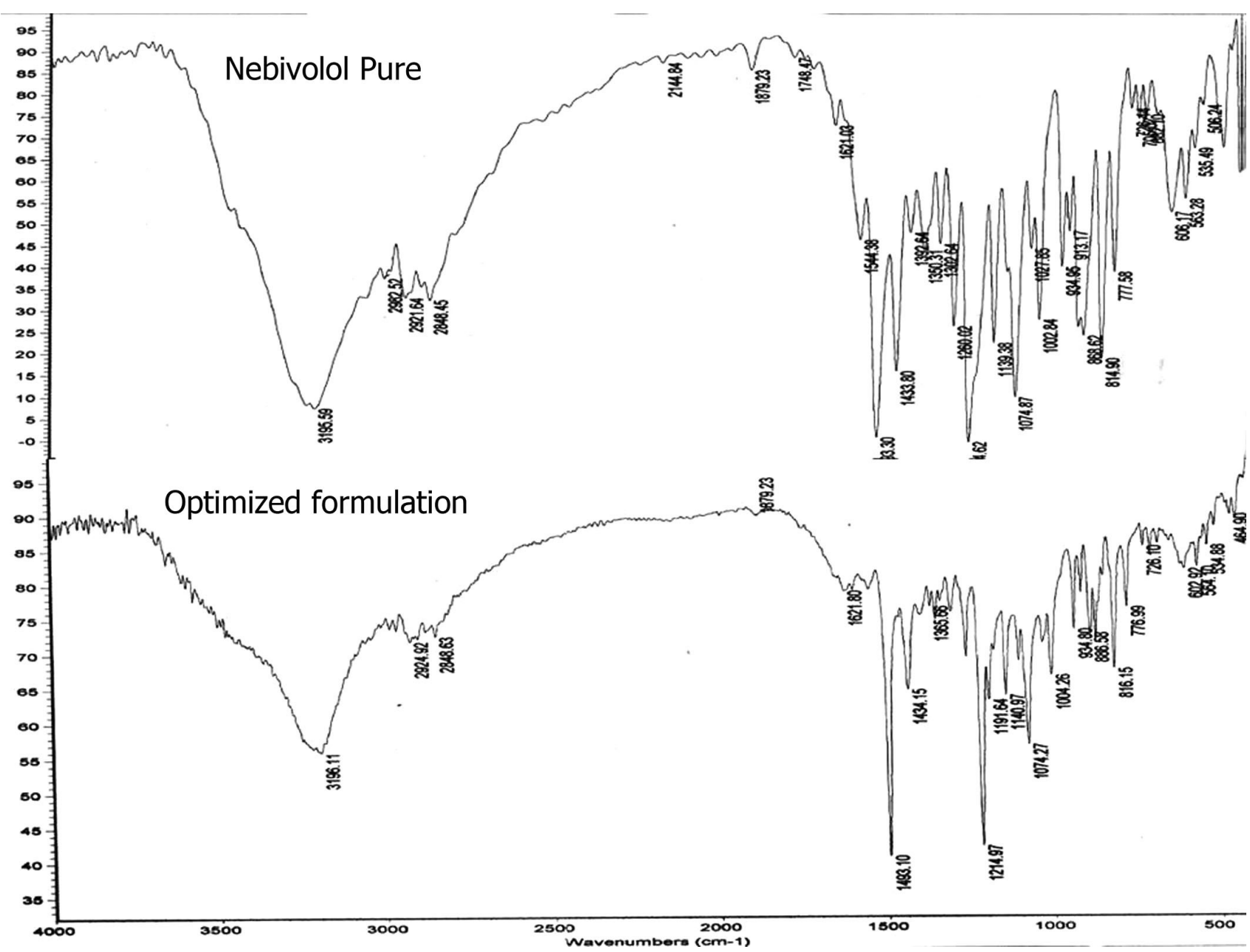

FIGURE 1 - IR-spectrum of pure nebivolol (A); IR-spectrum of Physical mixture of OEG formulation (B). Scans were performed from $400-4000 \mathrm{~cm}^{-1}$. Average of 40 scans was taken.

\section{A Nebivolol pure}

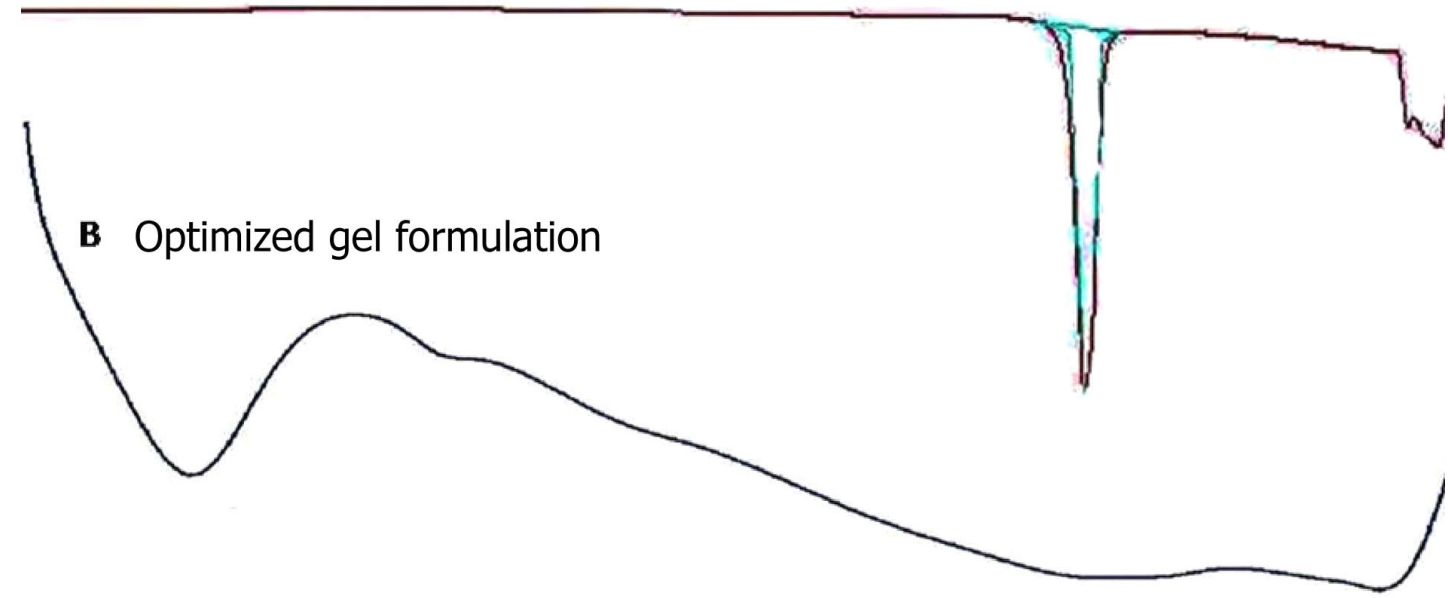

FIGURE 2 - DSC curve of pure nebivolol (A); optimized OEG formulation (B). 
lingual shear rates (Germain, Dufresne, Ramaswamy, 2006). However, there is little, or no consensus between different studies with the values ranging from 5 to 1000/s (Germain, Dufresne, Ramaswamy, 2006). Nevertheless, the shear rate value of $50 / \mathrm{s}$ is widely accepted for estimation purposes (Steele, Van Lieshout, Goff, 2003).

In our studies, all the samples were found to be shear thinning in behavior as they exhibited a reduction in viscosity with increasing shear rate. We studied the effect of sodium citrate concentration on viscosity of gels formed with increasing amount of polymer. Data is shown in Table II. As one may expect, there was linear increase in viscosity with increasing polymer concentration. However, when we compared viscosities of different formulations, there was a significant $(p<0.05)$ difference between viscosities of gels formed with $0.4 \% \mathrm{w} / \mathrm{v}$ and $0.5 \%$ $\mathrm{w} / \mathrm{v}$ gellan gum when different concentration of sodium citrate $(0.3$ and $0.5 \% \mathrm{w} / \mathrm{v})$ were used. Data depicted in Figure 3.

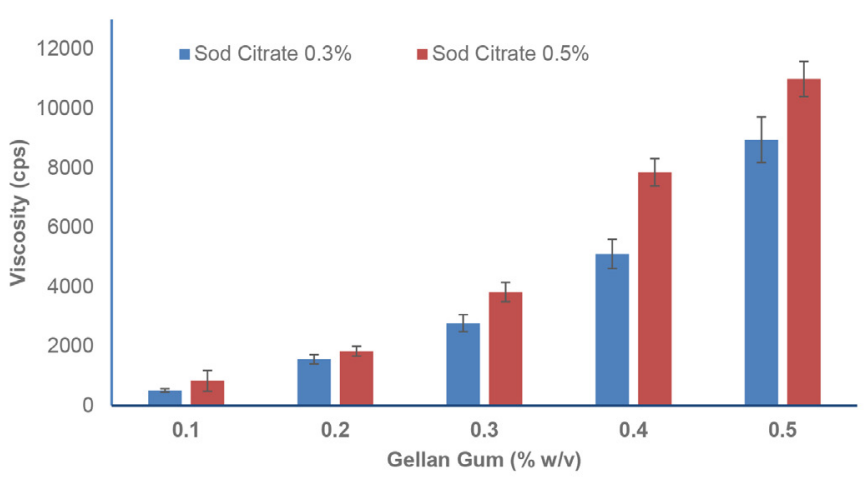

FIGURE 3 - Effect of sodium citrate concentration $(0.3 \%$ and $0.5 \% \mathrm{w} / \mathrm{v}$ ) on viscosity of OEG formulations with increasing gellan gum concentration $(0.1 \%$ to $0.5 \% \mathrm{w} / \mathrm{v})$.

Apparently, sodium citrate provides cations that cause inter and intra cross linking of gellan gum's polymeric chains leading to an increase in viscosity (Gohel et al., 2009). This was not very evident at lower polymer concentration because apparently the amount of cations provided by sodium citrate is in far excess. At higher polymer concentration, with increase in sodium citrate levels, more inter chain cross linking occurs leading to a significant increase in viscosity.

\section{Drug content assay}

The drug content was determined using HPLC after appropriate dilution (Sahoo, Giri, 2009). Experiment was performed in triplicate. The assay was within $95-105 \%$ of the label claim in all the tested formulations.

\section{In vitro drug release studies and release kinetics}

All the in vitro drug release studies were done in triplicate $(n=3)$. The optimized drug formulation showed over $95 \%$ drug release in 20 min (Figure 4). The drug release followed first order release kinetics. The Table III provides various parameters after fitting the drug release data of optimized formulation (F7) into different mathematical models. Based on the least square regression equation and obtained $\mathrm{r}^{2}$ values, the best-fit model was found to be first order model $\left(r^{2}=0.996\right)$.

TABLE III - Model fitting of optimized (F7) formulation

\begin{tabular}{lcc}
\hline Model & $\mathbf{r}^{\mathbf{2}}$ & $\mathbf{n}$ \\
\hline Zero Order & 0.404 & - \\
First Order & 0.996 & - \\
Higuchi & 0.904 & - \\
Korsmeyer-Peppas & 0.988 & 0.264 \\
Hixson-Crowell & 0.971 & - \\
\hline
\end{tabular}

\section{Stability}

The optimized edible gel formulations were stored at $25^{\circ} \mathrm{C} \pm 0.2{ }^{\circ} \mathrm{C} / 60 \pm 5 \% \mathrm{RH}$ and $40{ }^{\circ} \mathrm{C} \pm 0.2{ }^{\circ} \mathrm{C} / 75 \pm 5 \% \mathrm{RH}$ in a stability chamber (Ostwald stability chamber JRIC-11) for a period of 6 and 3 months respectively. It was observed that, gels stored at $40{ }^{\circ} \mathrm{C} / 75 \% \mathrm{RH}$ became physically unstable. Syneresis was observed in this condition. However, no physical/chemical changes were evident in the formulation at $25{ }^{\circ} \mathrm{C} / 60 \% \mathrm{RH}$. The data presented in Figure 5.

\section{In vivo studies}

Formulation F7 was optimized as it showed 95\% drug release in $20 \mathrm{~min}$ and was free from syneresis and grittiness. Formulations F1-F4 did not form gel while, F5F6 took a longer time to form gel. Formulations, F8-F10 formed viscous gels and showed a retarded drug release as compared to F7. Considering these factors, formulation F7 was optimized and selected for in-vivo pharmacokinetic studies in male New Zealand white rabbits $(n=6$, $n=3$ for each formulation). The time $v s$ plasma drug concentration data obtained from pharmacokinetic studies are presented in Figure 6. Unpaired Student t-test was used to compare the significance between means of two groups at $90 \%$ confidence interval. From the figure, it is evident that, compared to marketed formulations, there was a significant difference $(\mathrm{p}<0.1)$ in $\mathrm{T}_{\max }$ and $\mathrm{C}_{\max }$ values of 

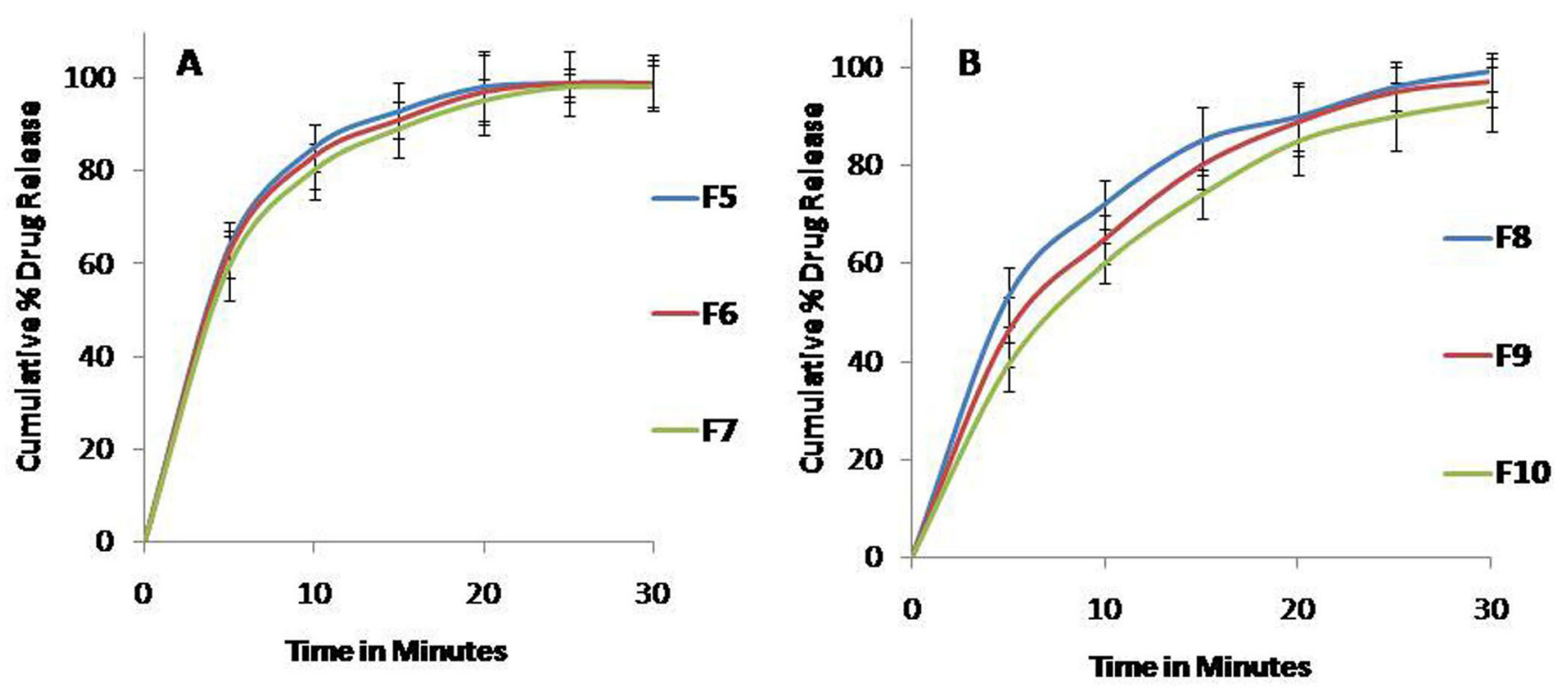

FIGURE 4 - In vitro drug release profile in pH 6.8 buffer for OEG formulations F5-F7 (A) and F8-F10 (B).

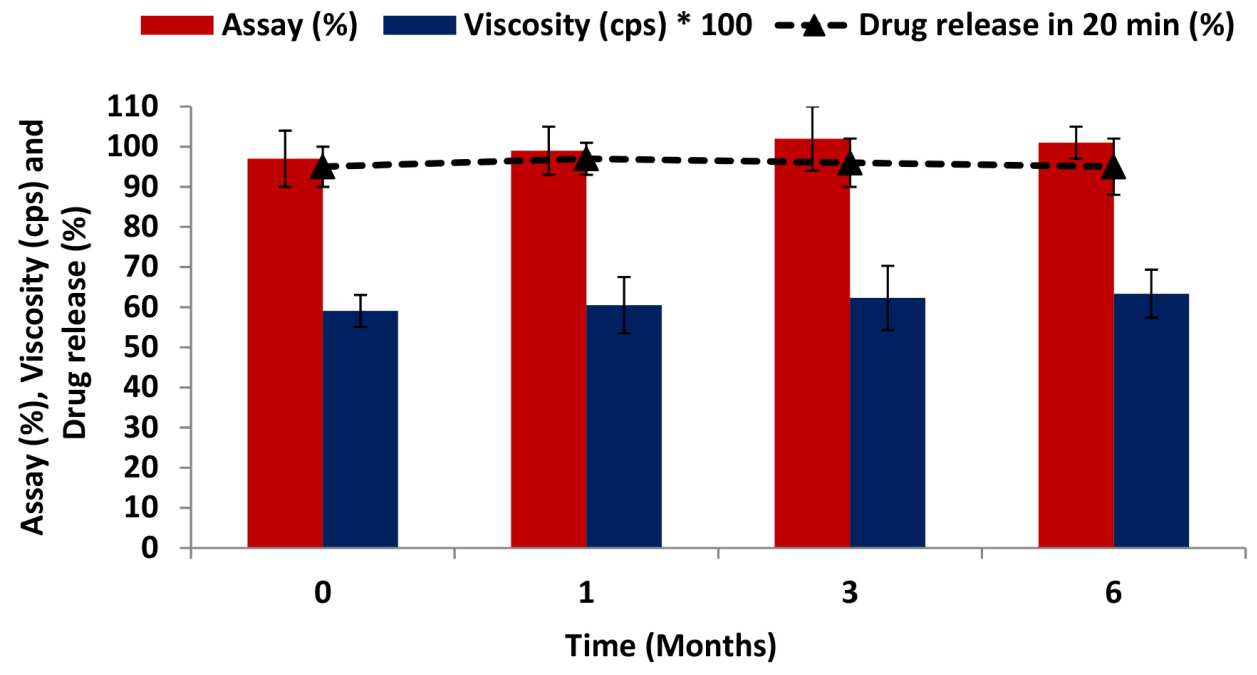

FIGURE 5 - Stability data of the optimized OEG formulation.

the gel formulation. Early $\mathrm{T}_{\max }$ was achieved $(45 \mathrm{~min})$ in the gel formulation.

The method reported by Punna Rao et al. was used for analysis of drug plasma samples after suitable partial validation in rabbit plasma (Punna Rao et al., 2015). No interfering peaks were seen at the drug's RT in the rabbit plasma matrix. A representative chromatogram for the same is shown in Figure 7.

Higher $\mathrm{C}_{\text {max }}$ and earlier $\mathrm{T}_{\max }$ was achieved in case of the gel formulation compared to conventional marketed product. This was attributed to a higher rate of dissolution, better solubility and by pass of the first pass metabolism (Ketan, Anuradha, Jignasa, 2012). This was further confirmed by comparing $\mathrm{AUC}_{0-\mathrm{t}}$ of the formulations. Design of edible gel formulation can bypass first pass effect because some percentage of drug gets absorbed through buccal cavity, thus avoiding first pass effect. Compared to marketed formulation, the gel formulation showed similar $\mathrm{AUC}_{0-\mathrm{t}}$ profiles $\left(\mathrm{F}_{\text {rel }}=102 \%\right)$. Nevertheless, the authors wish to draw the attention of the reader to the fact that in these studies, the number of animals used in the experiments were small ( $n=3$ in each group). Therefore, though the results of this study appear promising, it would be prudent to validate the results in a larger group of animals across different species before extrapolating the same to humans. The pharmacokinetic parameters are summarized in Table IV. 


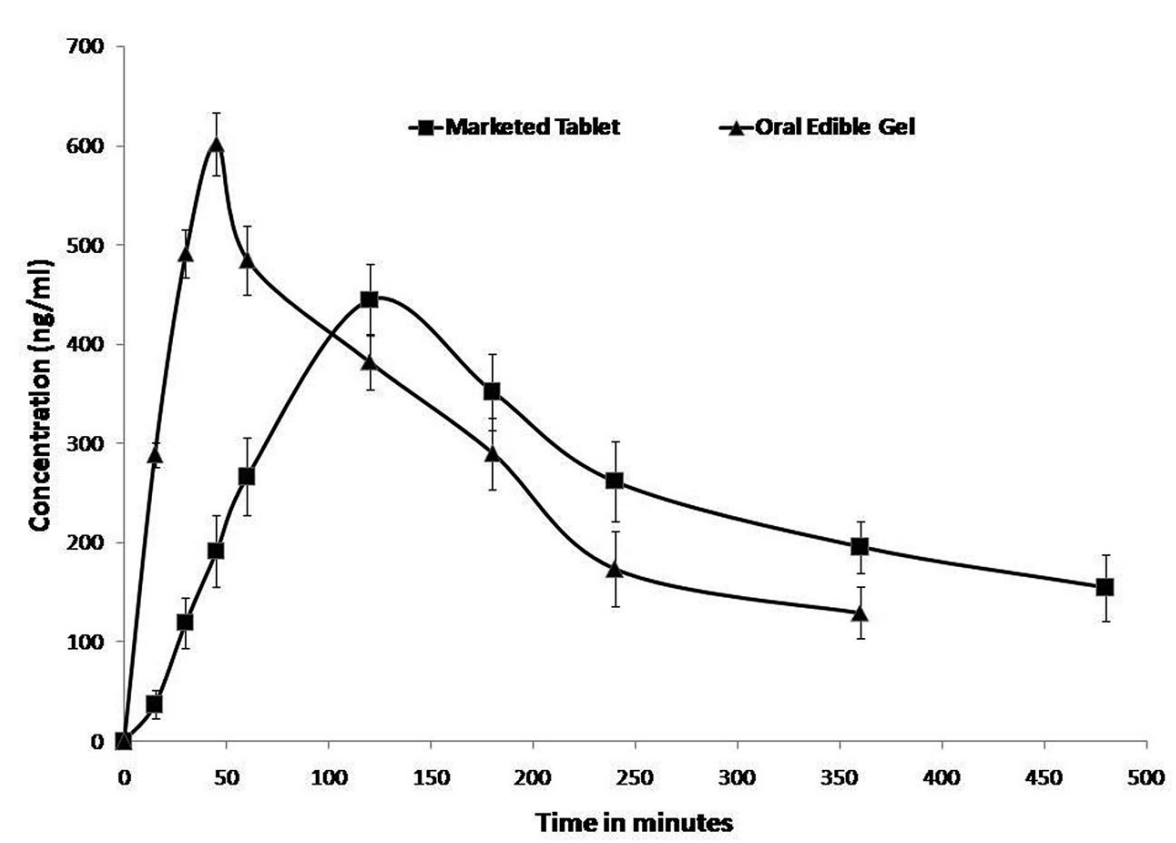

FIGURE 6 - Plasma concentration-time profile of nebivolol in New Zealand white rabbits followed by oral administration of marketed immediate release tablets and optimized OEG formulation $(10 \mathrm{mg} / \mathrm{kg}, n=3)$.
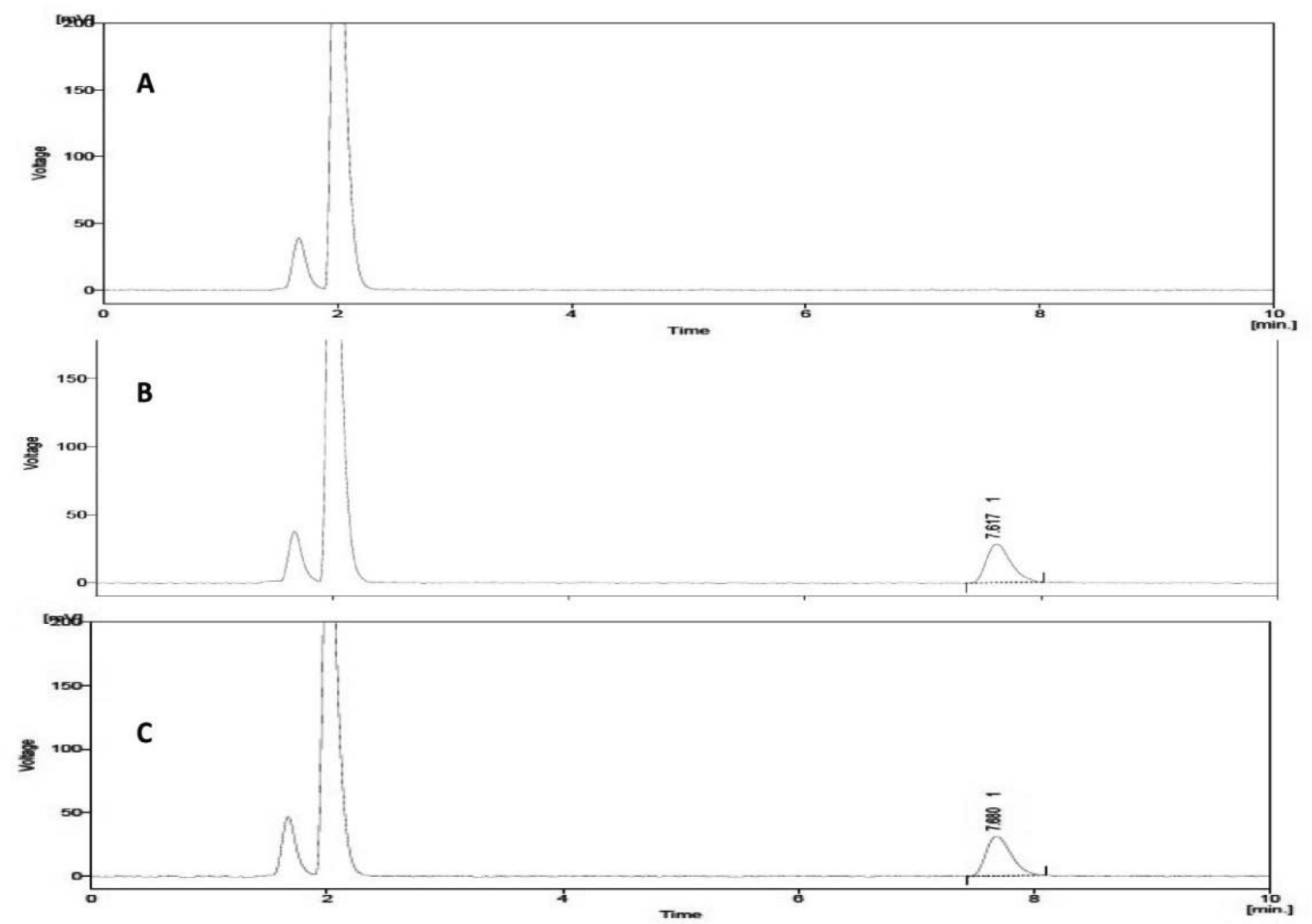

FIGURE 7 - Overlaid HPLC chromatograms of blank plasma matrix (A), externally spiked plasma sample (250 ng/mL) (B) and sample from actual pharmacokinetic study (C). Drug peak at $7.6 \mathrm{~min}$ RT is from the analyte nebivolol. 
TABLE IV - Pharmacokinetic parameters of nebivolol after oral administration of marketed and edible gel formulation to New Zealand white rabbits $(10 \mathrm{mg} / \mathrm{kg}, n=3)$

\begin{tabular}{lcc}
\hline Parameter & Marketed formulation & Gel formulation \\
\hline $\mathrm{C}_{\max }(\mathrm{ng} / \mathrm{mL})$ & $445.15 \pm 28.14$ & $602.35 \pm 36.32^{*}$ \\
$\mathrm{~T}_{\max }(\min )$ & 60 to 120 & 30 to $45^{*}$ \\
$\mathrm{AUC}_{(0-\mathrm{t})}(\mathrm{ng} / \mathrm{mL} * \mathrm{~min})$ & $119607.76 \pm 4563.32$ & $122812.398 \pm 5323.18^{*}$ \\
$\mathrm{~F}_{\mathrm{rel}}(\%)$ & - & 102 \\
\hline
\end{tabular}

Each value represents the mean $\pm \mathrm{SD}(n=3)$. $* \mathrm{p}<0.01$ compared to marketed formulation.

\section{CONCLUSION}

In this study, we have made systematic efforts to prepare edible gel formulation of NEB by using gellan gum. Edible gel formulation could significantly reduce the time taken to reach peak plasma concentration $\left(\mathrm{T}_{\max }\right)$ and maximum plasma concentration $\left(\mathrm{C}_{\max }\right)$ with comparable bioavailability. Based on these preliminary studies, the gel formulation appears better than the conventional tablets for dysphasic patients. However, thorough clinical investigation is necessary before extrapolating the results to humans.

\section{ACKNOWLEDGEMENTS}

The authors are thankful to Sri Venkateshwara College of Pharmacy, Madhapur, Hyderabad, for constant support and encouragement to complete this research work. Authors also would like to thank Mr. Aditya N for his help in pharmacokinetic calculations and proof reading.

\section{REFERENCES}

AMERICAN SPEECH-LANGUAGE-HEARING ASSOCIATION. (ASHA). Videofluoroscopy Swallowing Study (VFSS). Available at: <http://www.asha.org/public/ speech/swallowing/VFSS.htm>. Access on: Sep., 2014.

BISCH, E.M.; LOGEMANN, J.A.; RADEMAKER, A.W.; KAHRILAS, P.J.; LAZARUS, C.L. Pharyngeal effects of bolus volume, viscosity, and temperature in patients with dysphagia resulting from neurologic impairment and in normal subjects. J. Speech Hear Res., v.37, n.5, p. 10411059, 1994.

BYSTOLIC ${ }^{\circledR}$. Package insert. St. Louis: Forest laboratories, 2007.
DABHI, M.; GOHEL, M.; PARIKH, R.; SHETH, N.; NAGORI, $\mathrm{S}$. Formulation development of ambroxol hydrochloride soft gel with application of statistical experimental design and response surface methodology. PDA J. Pharm. Sci. Technol., v.65, n.1, p.20-31, 2011.

DANTAS, R.O.; KERN, M.K.; MASSEY, B.T.; DODDS, W.J.; KAHRILAS, P.J.; BRASSEUR, J.G. Effect of swallowed bolus variables on oral and pharyngeal phases of swallowing. Am. J. Physiol., v.258, n.5, p.675-681, 1990.

DIXIT, A.S.; KULKARNI, P.K. Novel eatable silk fibroin gels containing salbutamol sulphate for dysphagic and geriatric patients. Asian J. Pharm., v.6, p.60-66, 2012.

DIXIT, A.S.; PARTHASARATHI, K.K.; HOSAKOTE, G.S. Gels and jellies as a dosage form for dysphagia patients: a review. Curr. Drug Ther., v.6, n.2, p.79-86, 2011.

DUKE HEALTH. Videofluoroscopy Swallow Study (Modified Barium Swallow). 2007. Available at: <http://www. dukehealth.org/cancer/health_library/care_guides/ treatment_instructions/videofluoroscopicswallowstudy>. Accessed on: Sep., 2014.

GARY, M.; CATHY, P.; CATRIONA, S. National Dysphagia diet: what to swallow. ASHA Leader, v.8, p.16-27, 2003. Available at: $<$ http://www.asha.org/Publications/ leader/2003/031104/f031104c/>. Accessed on: Sep., 2014.

GERENTES, P.; VACHOUD, L.; DOURY, J.; DOMARD, A. Study of a chitin-based gel as injectable material in periodontal surgery. Biomaterials, v.23, n.5, p.1295-1302, 2002.

GERMAIN, I.; DUFRESNE, T.; RAMASWAMY, H.S. Rheological characterization of thickened beverages used in the treatment of dysphagia. J. Food Eng., v.73, n.1, p.64-74, 2006. 
GOHEL, M.C.; PARIKH, R.K.; NAGORI, S.A.; SHAH, S.N.; DABHI, M.R. Preparation and evaluation of soft gellan gum gel containing paracetamol. Indian J. Pharm. Sci., v.71, n.2, p.120-124, 2009.

HANAWA, T.; WATANABE, A.; TSUCHIYA, T.; IKOMA, R.; HIDAKA. M.; SUGIHARA, M. New oral dosage form for elderly patients: Preparation and characterization of silk fibroin gel. Chem. Pharm. Bull., v.43, n.2, p.284-288, 1995.

HILAS, O.; DANIELLE, E. Nebivolol (Bystolic), a novel beta blocker for hypertension. Pharm. Ther, v.34, n.4, p.188199, 2009.

JACKSON, L.D.; LITTLE, J.; KUNG, E.; WILLIAM, E.M.; SIEMIATKOWSKA, K.; PLOWMAN, S. Safe medication swallowing in dysphagia: a collaborative improvement project. Healthc. Q., v.11, n.3, sp.iss., p.110-116, 2008.

KETAN, T.S.; ANURADHA, K.G.; JIGNASA, K.S. Drug solubility: importance and enhancement techniques. ISRN Pharm., v.1, p.1-10, 2012.

KISHORE, K.; MADDI, V.N.; SAMBASIVA, R.K.R.S.; BHIKSHAPATHI, D.V.R.N. Preparation and in-vivo evaluation of oral dissolving films containing sumatriptan succinate. Pharm. Lett., v.5, p.27-38, 2013.

MALYSZKO, J.; MUNTNER, P.; RYSZ, J.; BANACH, M. Blood pressure levels and stroke: J-curve phenomenon? Curr. Hypertens. Rep., v.15, n.6, p.575-581, 2013.

MOHAPATRA, A.; PARIKH, R.K.; GOHEL, M.C. Formulation, development and evaluation of patient friendly dosage forms of metformin. Part-II: Oral soft gel. Asian J. Pharm., v.2, p.172-176, 2008.

PHARMACY BENEFITS MANAGEMENT. PBM. Guidance for medication assessment in patients with Swallowing (Dysphagia) or feeding disorders pharmacy benefits management-Strategic Healthcare Group (PBM). 2006. Available at: <http://www.pbm.va.gov/clinicalguidance/ clinicalrecommendations/DysphagiaRecommendationsf orMedicationAssessment.pdf>. Accessed on: Aug. 2014.

PUNNA RAO, R.; ADITYA, N.; HIMANSHU, K.; SRINIVAS, M.; RAHUL, V. Lipid nanoparticles for oral delivery of raloxifene: optimization, stability, in vivo evaluation and uptake mechanism. Eur. J. Pharm. Biopharm., v.87, n.1, p.114-124, 2014.
PUNNA RAO, R.; RAHUL, V.; SHAILENDER, J.; NITIN, G. Development and validation of simple, rapid and sensitive LC method for quantification of nebivolol in rat plasma and its application to pharmacokinetic studies. Acta Chromatogr., v.27, n.2, p.281-294, 2015.

RAJU, S.; SANDEEP, R.P.; ANIRUDH, K.V.; DEEPTHI, A.; SREERAMULU, R.K.; MADHAVA, R.P.V. Flash release oral films of metoclopramide hydrochloride for pediatric use: formulation and in-vitro evaluation. J. Chem. Pharm. Res., v.3, p.636-646, 2011.

SAHOO, M.K.; GIRI, R.K. RP-HPLC Method for the estimation of nebivolol in tablet dosage form. E-J. Chem., v.6, p.915919, 2009.

SETOUHY, S.A.E.; MALAK, N.S.A.E. Formulation of a novel tianeptine sodium orodispersible film. AAPS PharmSciTech., v.11, n.3, p.1018-1025, 2010.

SHIRLEY, L.S. Difficulty swallowing can be fatal for people with Parkinson's. 2013. Available at: <http://www. parkinson.org/About-Us/Press-Room/NPF-In-TheNews/2013/January/Difficulty-swallowing-can-be-fatalfor-people-with>. Accessed on: Aug. 2014.

STEELE, C.M.; VAN LIESHOUT, P.H.; GOFF, H.D. The rheology of liquids: a comparison of clinicians' subjective impressions and objective measurement. Dysphagia, v.18, n.3, p.182-195, 2003.

UNITED States Pharmacopeia: USP 24. National Formulary: NF 19. Rockville: United States Pharmacopoeia Convention, 2000. p.1913-1914.

WEXNER MEDICAL CENTER. Thickened liquids consistency for safer swallowing. 2013. Ohio: The Ohio State University, 2013. 4p. Available at: $<$ http://patienteducation. osumc.edu/Documents/thickened-liquids.pdf $>$. Accessed on: Aug. 2014.

Received for publication on $17^{\text {th }}$ December 2014 Accepted for publication on $28^{\text {th }}$ July 2015 
